\title{
The distribution patterns of exploited girellid, kyphosid and sparid fishes on temperate rocky reefs in New South Wales, Australia
}

\author{
MICHAEL KINGSFORD \\ School of Marine Biology and Aquaculture, Jomes Cook University, Townsville, Queensland 4811, Australia \\ MichoelKingsford@jcuedu.au)
}

SUMMARY: Girellids and sparids rank highest as the groups of fishes taken by rock fishers in New South Wales, Australia. Rapid visual counts that were stratified by depth and transects that were stratified by habitat (e.g. kelp forest and urchin grazed barrens) showed that girellids were most abundant in shallow water (<3m deep). A few aggregations (primarily Girella tricuspidata) were found in waters up to $15 \mathrm{~m}$ deep. No juvenile G. tricuspidata were observed on reefs, all of the fish in counts were greater than $200 \mathrm{~mm}$ SL. In contrast, $G$. elevata of all size classes (30-300 $\mathrm{mm} \mathrm{SL}$ ) were found in water less than $3 \mathrm{~m}$ deep. Almost all Kyphosus (98\%) were in shallow water. Sparids (57\%) were found in shallow water, although some (Pagrus auratus) were only found in deep or mid-depth strata. Girellids, kyphosids and some sparids used the intertidal at high tide. Girellids were observed to feed in the shallows. Juvenile G. elevata $(30-70 \mathrm{~mm} \mathrm{SL})$ fed in the intertidal mostly on rocky surfaces, tubeworms and the backs of large limpets (Cellana spp.) where algae were abundant. Shallow waters and the intertidal of rocky reefs have probably been underestimated in terms of importance to fisheries.

\section{KEYWORDS: Girellidae, Sparidae, Kyphosidae, temperate reef, depth, habitat}

\section{INTRODUCTION}

Girellids are the most important recreational fish species taken by fishers on reefs in New South Wales, Australia. ${ }^{1)}$ Although girellids are found on temperate reefs in Australia, the Pacific coast of North America, ${ }^{2)}$ South America ${ }^{3)}$ and Japan (pers. obs.), there are few data on their ecology. Girella tricuspidata are known to recruit to estuaries in large numbers and are thought to move to open coastal rocky reefs as subadults and juveniles, ${ }^{4,5}$ as for other fishes such as Achoerodus viridis (Labridae; ${ }^{6}$ ). In contrast, Girella elevata are rarely found in estuaries. These fish have been collected on rocky reefs ${ }^{7}$ and $60 \%$ or more of the diet for fish of all sizes is algae. ${ }^{8)}$ Kyphosids (Kyphosus sydneyarmus) and sparids (Acanthopagrus australis, Rhabdosargus sarba and Pagrus auratus) also rank highly in the catches of fishers and were also considered in this study. Girellids consume considerable quantities of algae, but are omnivorous, Kyphosus are obligate herbivores" and sparids are predators.

Studies in temperate waters of California and New Zealand have found that abundance patterns of fishes are often influenced by the presence of different habitat types (review: ${ }^{10}$ ). Habitats are generally distinguished by the type and cover of algae. Sea urchins and limpets have important roles in maintaining areas devoid of algae [sensu: 'Barrens' habitat, ${ }^{11)}$ in temperate waters of Australia and New Zealand (review: ${ }^{12}$ )]. In addition to habitat type, the distribution of fishes often varies with depth on a reef $\left(\mathrm{eg}^{10}\right)$.
The confounding influence of depth and habitat can only be resolved if habitats are found in a mosaic over the same depth range, as for New South Wales, ${ }^{11)}$ and/or habitats are experimentally manipulated. It is also well known that different approaches may be required to look for secretive juveniles versus highly mobile adults. Multiple approaches were used in this study.

The objective of this study was to describe the distribution patterns of girellid, kyphosid and sparid fishes on rocky reefs in New South Wales, particularly the Sydney region. My specific aims were to: (1) describe the depth related patterns of highly mobile fishes using rapid visual counts, because girellids, kyphosids and sparids are generally diver negative; (2) describe patterns of abundance of fishes over a broad depth range where sampling was stratified according to habitat; (3) intensively sample the intertidal at high tide to describe the utilization of this area by fishes. Some girellids (eg. Girella nigricans, ${ }^{2}$; Girella laevifrons, $\left.{ }^{3}\right)$ use shallow areas including rock pools, but sampling was not done at high tide in these studies.

\section{MATERIALS AND METHODS}

Taxonomy was according to Hutchins and Swainston ${ }^{13)}$

Rapid visual counts of girellids and sparids

Rapid visual counts are useful for estimating the abundance of large fishes that are typically diver negative or are found 
in large groups that are well separated (eg. $\left.{ }^{10}\right)$. In New South Wales large herbivores (eg. Girella tricuspidata) and some carnivores (eg. Acanthopagrus custralis) behave in one or both of these ways. Counts were stratified by depth [shallow (0-3m), mid (4-10m), deep (11-20m)] and 5x3min replicate counts were done at each depth. In a three-minute period I swam a distance of approximately $45 \mathrm{~m}$. Fishes were counted at four random times between May 1987 and May 1988 at three locations along the coast of NSW: Botany Bay $\left(34^{\circ} 0^{\prime} \mathrm{S}, 151^{\circ} 10^{\prime} \mathrm{E}\right)$, Bass Point $\left(34^{\circ} 30^{\prime} \mathrm{S}\right.$, $\left.151^{\circ} 50^{\prime} \mathrm{E}\right)$ and Jervis Bay $\left(35^{\circ} 10^{\prime} \mathrm{S}, 150^{\circ} 30^{\prime} \mathrm{E}\right)$. Two sites separated by $0.5-1 \mathrm{~km}$ were sampled at each location. Data were analysed using a 4-factor partially-hierarchical ANOVA; factors: depth (fixed), time, location and site (nested within location). The latter factors were treated as random. Data were $\log (x+1)$ transformed.

\section{Fish counts stratified by habitat}

Most of the habitats were described in ${ }^{11)}$ and were classified as follows: 'Shallow broken rock' $(0.5-2 \mathrm{~m})$, the 'Fringe' (2-3m), urchin grazed 'Barrens' (4-12m), Ecklonia radiata dominated kelp forest (4-12m) and 'Deep reef' (15-22m). Fishes, especially secretive juveniles, were counted using the transect method. Transects measured $25 \times 5 m(n=6)$. A $25 \times 5 \mathrm{~m}$ transect size was chosen because they fitted easily within habitats and gave usable average values for a variety of species of fishes. Transects were non-overlapping. A detailed search was made under all boulders and/or amongst kelp for more cryptic fishes (eg. juveniles).

Fishes were counted in 5 habitats and at two sites separated by $200 \mathrm{~m}$ at Cape Banks ( $34^{\circ} 0^{\prime} \mathrm{S}, 151^{\circ} 10^{\prime} \mathrm{E}$ ). Counts were done at two times: January 1988 and May 1988. Patterns of abundance for fishes in shallow broken rock habitat were extracted from maps of the intertidal and immediate subtidal as described below. The standard length (SL) of fishes was estimated by eye, this method was calibrated periodically when fishes were collected for other reasons. Fishes were considered to be juveniles if they were less than $100 \mathrm{~mm}$ SL.

\section{Fish counts in the intertidal}

Two areas of the intertidal were mapped near Cape Banks and the position of fishes were plotted onto the maps: area $A=8000 \mathrm{~m}^{2}$ and area $B=6250 \mathrm{~m}^{2}$. Transect data (as for previous section) were extracted from maps using an acetate overlay of a $25 \times 5 \mathrm{~m}$ transect, the start point of the transect was determined using random numbers on the gridded maps. All transects were non-overlapping. The low tide mark determined the lowest side of each study area. The positions of fishes were plotted at area $\mathrm{A}$ on 7 occasions and 5 times at area B, due to bad weather (Table 1). Behavioural observations were made on snorkel for small
G. elevata; these fish were followed for 35 to 94 seconds. The bite rates of fish (per minute) were recorded and the substratum on which they were feeding. Observations were made within an area of lha.

Table 1 Abundance of reef fish in the intertidal at high tide ( $125 \mathrm{~m}^{2}, \mathrm{n}=6$ transects); mean (SE). ND denotes no data collected due to rough seas.

\begin{tabular}{|c|c|c|c|c|c|c|c|}
\hline \multirow{2}{*}{$\begin{array}{l}\text { Date (mo-yr) } \\
\text { Area }\end{array}$} & \multicolumn{2}{|l|}{$11-90$} & \multicolumn{2}{|l|}{$12-90$} & \multicolumn{2}{|l|}{ 02-91 } & \multirow{2}{*}{$\begin{array}{l}0491 \\
\mathrm{~A} \\
\end{array}$} \\
\hline & A & B & $\mathbf{A}$ & $\mathbf{B}$ & $\mathbf{A}$ & B & \\
\hline $\begin{array}{l}\text { Girella } \\
\text { bricuspidata }\end{array}$ & $\begin{array}{l}0.2 \\
(0.2)\end{array}$ & 0.0 & $\begin{array}{l}2.7 \\
(1.9)\end{array}$ & $\begin{array}{l}1.3 \\
(1.3)\end{array}$ & $\begin{array}{l}0.3 \\
(0.3)\end{array}$ & $\begin{array}{l}1.3 \\
(1.0)\end{array}$ & $\begin{array}{l}1.8 \\
(1.6)\end{array}$ \\
\hline Girella elevata & $\begin{array}{l}0.8 \\
(0.4)\end{array}$ & $\begin{array}{l}4.3 \\
(2.5)\end{array}$ & $\begin{array}{l}0.3 \\
(0.3)\end{array}$ & $\begin{array}{l}5.0 \\
(2.4)\end{array}$ & 0.0 & $\begin{array}{l}8.0 \\
(3.1)\end{array}$ & 0.0 \\
\hline $\begin{array}{l}\text { Kyphosus } \\
\text { sydneyanus }\end{array}$ & 0.0 & 0.0 & 0.0 & $\begin{array}{l}1.2 \\
(1.2)\end{array}$ & $\begin{array}{l}0.5 \\
(0.5)\end{array}$ & $\begin{array}{l}0.3 \\
(0.3)\end{array}$ & $\begin{array}{l}0.6 \\
(0.4)\end{array}$ \\
\hline $\begin{array}{l}\text { Acanthopagnus } \\
\text { australis }\end{array}$ & $\begin{array}{l}0.3 \\
(0.3) \\
\end{array}$ & 0.0 & $\begin{array}{l}13 \\
(1.0) \\
\end{array}$ & 0.0 & $\begin{array}{l}0.5 \\
(0.5) \\
\end{array}$ & $\begin{array}{l}0.3 \\
(0.3) \\
\end{array}$ & $\begin{array}{l}0.6 \\
(0.4) \\
\end{array}$ \\
\hline Date (mo-yr) & $04-91$ & $06-91$ & & $12-91$ & & 0492 & \\
\hline Area & B & $\mathbf{A}$ & $\mathbf{B}$ & $\mathbf{A}$ & B & $\mathbf{A}$ & B \\
\hline $\begin{array}{l}\text { Girella } \\
\text { tricuspidata }\end{array}$ & $\mathrm{ND}$ & $\begin{array}{l}5.0 \\
(3.0)\end{array}$ & ND & $\begin{array}{l}8.0 \\
(6.0)\end{array}$ & $\begin{array}{l}12.0 \\
(11.0)\end{array}$ & $\begin{array}{l}5.0 \\
(4.0)\end{array}$ & $\begin{array}{l}1.2 \\
(0.5)\end{array}$ \\
\hline Girella elevata & ND & $\begin{array}{l}0.7 \\
(0.7)\end{array}$ & ND & $\begin{array}{l}2.0 \\
(1.2)\end{array}$ & $\begin{array}{l}3.3 \\
(2.0)\end{array}$ & $\begin{array}{l}1.3 \\
(0.8)\end{array}$ & $\begin{array}{l}4.3 \\
(2.4)\end{array}$ \\
\hline $\begin{array}{l}\text { Kyphosus } \\
\text { sydneyousus }\end{array}$ & $\mathrm{ND}$ & 0.0 & ND & $\begin{array}{l}1.7 \\
(1.3)\end{array}$ & 0.0 & 0.0 & 0.0 \\
\hline $\begin{array}{l}\text { Acanthopagrus } \\
\text { australis }\end{array}$ & ND & $\begin{array}{l}0.7 \\
(0.4) \\
\end{array}$ & ND & $\begin{array}{l}0.3 \\
(0.2) \\
\end{array}$ & $\begin{array}{l}0.2 \\
(0.2) \\
\end{array}$ & $\begin{array}{l}1.3 \\
(0.6) \\
\end{array}$ & 0.0 \\
\hline
\end{tabular}

\section{RESULTS}

\section{Rapid Visual Counts of Sparidae, Girellidae and Kyphosus}

Girellids (90\%, $\mathrm{n}=1093)$ and Kyphosus sydneyomus (98\%, $n=43$ ) were most abundant in very shallow water (Fig. 1). This pattern was consistent among times, locations and sites. On some occasions few fish of a given species were found in the shallows. This suggested that all of these species move over spatial scales greater than those addressed in this study (ie. $>1 \mathrm{~km}$ ). Variation in abundance resulted in a depth $\mathrm{x}$ location $\mathrm{x}$ time interaction. Girella tricuspidata $(\mathrm{n}=602,200-350 \mathrm{~mm} \mathrm{SL}), G$. elevata $(\mathrm{n}=489,30-300 \mathrm{~mm}$ SL) and $G$. zebra $(\mathrm{n}=9,100-340 \mathrm{~mm} \mathrm{SL})$ were observed in counts.

Sparids were found at all depths on reefs, but the greatest percentage of fish was found in shallow water $(57 \%, n=490$, Fig. 1). ANOVA detected differences in the rank of sparid abundance at locations among times and significant differences were found among sites within times. The percentages of fish found at shallow, mid and deep strata were as follows: Acanthopagrus australis $(67,16$, $17 \%, \mathrm{n}=353)$, Rhabdosargus sarba $(42,25,34 \%, \mathrm{n}=101)$, Pagrus auratus $(0,29,71 \%, \mathrm{n}=35)$.

Most of the $A$. custralis and $R$ sarba were juveniles (SL: $240-350 \mathrm{~mm}, 200-300 \mathrm{~mm}$ respectively), while the $P$. ouratus were primarily juveniles $(70-140 \mathrm{~mm} \mathrm{SL})$. 
A high proportion (30-70\%) of the catch by recreational fishermen in the Sydney area were G. tricuspidata and A. custralis. ${ }^{1)}$ The fishes they caught were of a similar size

Girellidae
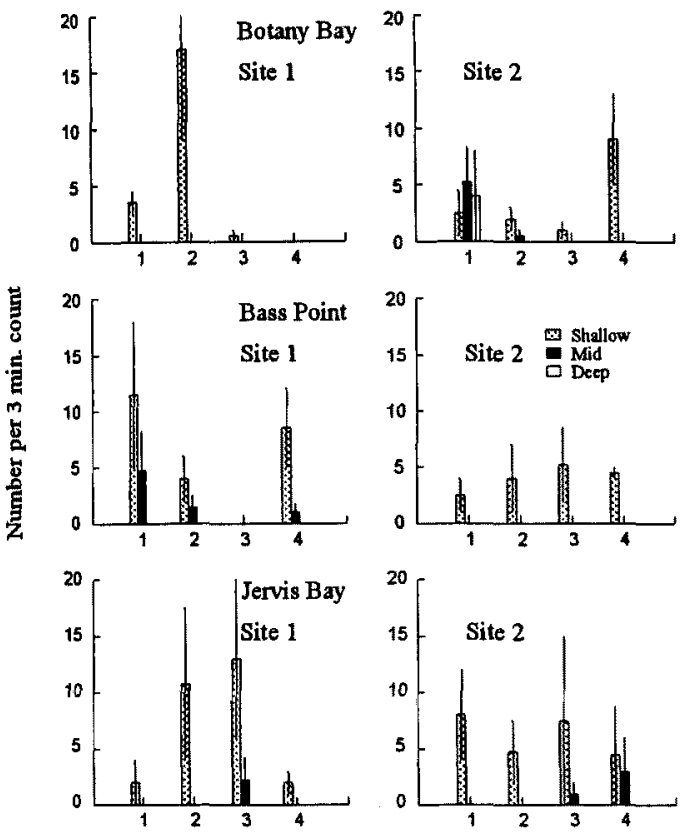

Sparidae

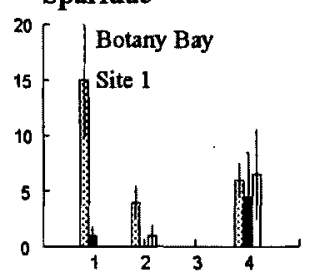

Time
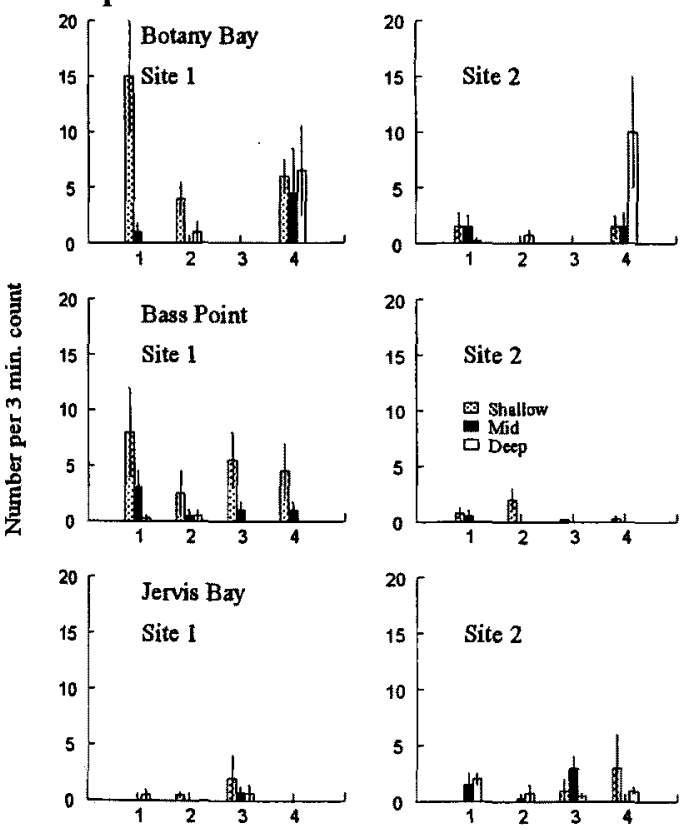

Time

Fig, 1 Abundance of girellid and sparid fishes at different depths, locations, sites and times, mean \pm SE. Results of ANOVAs: Girellidae: a depth x location $x$ time interaction was significant (df 12,18, F=3, p<0.025); Sparidae: a location $x$ time (df 6,9 F=8.98, $\mathrm{P}<0.01$ ) and site (location) was significant (df $3,9, \mathrm{~F}=$ $10.8, p<0.01)$

range [mean SL (range): Girella spp. $330 \mathrm{~mm}(130-480 \mathrm{~mm}$, $\mathrm{n}=181), A$. coustralis $240 \mathrm{~mm}(100-400 \mathrm{~mm}, \mathrm{n}=91)]$ to those

observed in shallow water in this study (for sampling design $s e e^{1)}$.

\section{Abundance patterns of fishes in subtidal habitats}

Girellids were abundant in the study area. In general, patterns of abundance were consistent among habitats and times. Girella elevata were only found in shallow habitats (Fig. 2). Very high numbers of these fish were found and a high proportion of them were juveniles $(75 \%<70 \mathrm{~mm} \mathrm{SL})$. Girella tricuspidata were observed outside of transects (see section: 'Rapid visual counts of girellids and sparids').

\section{Abundance of fishes in the intertidal at high tide}

Great numbers of girellids were observed grazing and swimming in the intertidal at high tide (Table 1). Large groups of Girella tricuspidata and Girella elevata were observed feeding on tufting algae, particularly where solitary ascidians ('cunjei' Pyura stolonifera) and/or Ulva covered a large percentage of the substratum (pers. obs.). All of the G. tricuspidata were over $250 \mathrm{~mm} \mathrm{SL}$ and large G. elevata were $150-300 \mathrm{~mm}$ SL. Juvenile G. elevata (Fig. 3) were observed feeding at mean bite rates of 6.9 bites per $\min (\mathrm{SE}=1.6 ; \mathrm{n}=29$ fish; 30-70mm SL). Fifty-eight percent of bites were on rock, $28 \%$ on tubeworms (Galeolaria), $9.7 \%$ on the backs of limpets (Cellana spp.) and $4 \%$ on solitary ascidians and algal turf. Recruitment of juvenile G. elevata varied greatly among times; a mean density of 9 recruits per $125 \mathrm{~m}^{2}$ was recorded in 1988 (Fig. 2) and was much higher than mean densities of recruits recorded in 1990, 1991 and $1992\left(1.0,2.2,1.0\right.$ recruits per $125 \mathrm{~m}^{2}$ respectively).

Large and small predators were observed in the intertidal. Acanthopagnus australis (250-300mm SL) were seen in groups of up to six individuals in $<0.5 \mathrm{~m}$ of water, but only small numbers of these were seen.

Time 1

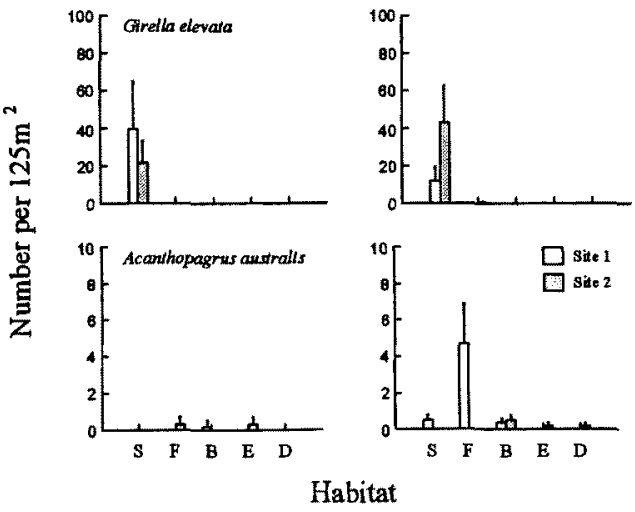

Fig. 2 Abundance of two species of fishes in 5 habitats, two sites and at two times, $\mathrm{S}=$ shallow broken rock, $\mathrm{F}=$ fringe, $\mathrm{B}$-barrens, $\mathrm{E}=$ Ecklonia laminarian forest. $D=$ deep reef. mean $t S E$. 


\section{DISCUSSION}

There were great differences in the representation of girellids, kyphosids and sparids with depth. The herbivores (girellids and kyphosids) predominated in shallow water. Although herbivorous fishes are common at temperate latitudes, ${ }^{14,15,16)}$ descriptions of their distribution patterns are limited despite their importance to recreational and commercial fisheries. Some taxa showed great variation in abundance among times (eg. Girella tricuspidata) indicating that they have poor site fidelity and appear to move around areas of reefs at spatial scales of over a kilometre, this concurs with casual observations by fishers.

There is a poor appreciation of how fishes utilise intertidal areas of rocky reefs in temperate regions. In my study, great numbers of girellids were found in the intertidal at high tide. Moreover, predatory Aconthopagrus australis were found in the intertidal. It cannot be assumed, therefore, that the effects of piscine herbivores and predators are negligible in the intertidal. For example, Parry ${ }^{17)}$ argued that Notolabrus fucicola adults were a potentially important predator on limpets in the intertidal of Victoria. Treatments that include fish removals are required where problems conceming predation or grazing in intertidal areas are to be addressed.

Of relevance to managers, there are two categories of girellids and kyphosids. $G$. tricuspidata recnuit to estuaries ${ }^{4)}$ and move to and from the open coast as adults. ${ }^{18)}$ In contrast, G. elevata and Kyphosus (pers. obs.) recruit to shallow water on rocky reefs and occupy the same habitat as adults. The sparids $A$. oustralis and Rhabdosargus sarba recruit in large numbers to estuaries and move to and from coastal reefs as adults. Pagrus ouratus appears to recruit to both reefs and estuaries (pers. obs.). Although only juveniles were observed at mid and deep strata on reefs (and this has been my experience over 14 years), adults and juveniles are common on reefs in New Zealand. ${ }^{19}$

In New South Wales, girellids and sparids (especially A. cuustralis) rank as the greatest part of the catch taken by recreational rock-fishermen. ${ }^{1)}$, these groups abound in shallow water $(<\mathrm{m}$ deep). Hence, management policies that are concerned with the protection of coastal resources should consider the importance of shallow water habitats. Furthermore, this conclusion may be generally applicable to girellids and kyphosids for other temperate regions $\left(\mathrm{eg}{ }^{16}\right)$.

\section{ACKNOWLEDGMENTS}

Financial support was provided by an MST grant to A.J. Underwood, and a University of Sydney Special Projects grant to M.J. Kingsford. Julian Hughes provided constructive criticisms.

\section{REFERENCES}

1. Kingsford MJ, Underwood AJ, Kennelly SJ. Humans as predators on rocky reefs in New South Wales, Australia Mar. Ecol Prog. Ser. 1991; 72: 1-14.

2. Norris $\mathrm{K}$. The functions of temperature in the ecology of the percoid fish Ginella nigricans (Ayers). Ecol. Monogr. 1963; 33: 2462.

3. Berrios Viviana L, Vargas Mauricio E. Intertidal fish assemblages structure of the rocky shore at the north of Chile. Revista de Biologia Marina y Oceanografia 2000; 35: 73-81.

4. McNeill SE, Worthington DG, Ferrell DJ, Bell JD. Consistently outstanding recruitment of five species of fish to a seagrass bed in Botany Bay, NSW. Aust. J. Ecol. 1992; 17: 359-365.

5. Gray CA, McElligott DJ, Chick RC. Intra- and inter-estury differences in assemblages of fishes associated with shallow seagrass and bare sand. Mar. Freshurat. Res. 1996; 47: 723-735.

6. Gillanders BM, Kingsford MJ. Elements in otoliths may elucidate the contribution of esturine recruitment to sustaining coastal reef populations of a temperate reef fish Mar. Ecol. Prog. Ser. 1996; 141: $13-20$

7. Gallahar NK, Kingsford MJ. Factors influencing $\mathrm{Sr} / \mathrm{Ca}$ ratios in Girella elevata: an experimental approach J. Fish Biol 1996; 48: 174-186.

8. Bell JD, Burchmore JJ, Pollard DA. The food and feeding habits of the rock blackfish, Girella elevata Macleay (Pisces:Girellidae), from the Sydney region, New South Wales Aust. J. Zool 1980, 20: $391-405$.

9 Clements $\mathrm{KD}$, Choat $\mathrm{JH}$ Comparison of herbivory in the closely-related marine fish genera Girella and Kyphosus. Mar: Biol. 1997; 127: 579-586.

10. Kingsford MJ. Reef fish In Kingsford MJ, Battershill $\mathrm{CN}$. Studying temperate marine enviromments: A handbook for ecologists. University of Canterbury Press, Christchunch, 1998, pp. 132-166.

11. Underwood AJ, Kingsford MJ, Andrew NL. Patterns in shallow subtidal marine assemblages along the coast of New South Wales. Aust. J. Ecol. 1991; 6: 231-249.

12. Kingsford MJ, Battershill CN. Subtidal habitats and benthic organisms. In Kingsford MJ, Battershill $\mathrm{CN}$. Stuxying temperate marine environments: A handbook for ecologists. University of Canterbury Press, Christchurch, New Zealand, 1998, pp. 84114.

13. Hutchins B, Swainston R. Sea fishes of southem Australia Swainston Publishing, Perth, 1986, pp. 180.

14. Hom MH Biology of Marine Herbivorous fishes. Oceanography and Marine Biology an Anmual Review 1989; 27: 167-272.

15. Choat JH The biology of herbivorous fishes on coral reefs. In Sale PF (ed) The ecology of fishes on coral reefs. Academic Press, San Diego, 1991, pp. 120-155.

16. Meekan MG, Choat $\mathrm{JH}$. Latitudinal variation in abundance of herbivorous fishes: a comparison of temperate and tropical reefs. Mar. Biol. 1997; 128: 373-384.

17. Parry GD. The evolution of the life histories of four species of intertidal limpets. Ecol. Monogr. 1982; 52: 65-91.

18. Morrison MA Ontogenetic shifts in the ecology of the parore Girella tricuspidata. MSc thesis, University of Auckland, 1990.

19. Kingett $\mathrm{PD}$, Choat JH. Analysis of density and distribution pattems in Chrysophrys auratus (Pisces: Sparidae) within a ref environment: an experimental approach. Mar. Ecol. Prog. Ser. 1981; 5: 283-290. 